Канівець Н. С., кандидат ветеринарних наук

Полтавська державна аграрна академія

\title{
ПОШИРЕННЯ ВИРАЗКОВОГО ГЛОСИТУ У ВЕЛИКОЇ РОГАТОЇ ХУДОБИ В ОКРЕМИХ ГОСПОДАРСТВАХ ПОЛТАВСЬКОГО РАЙОНУ
}

\section{Рецензент - кандидат ветеринарних наук Н. І. Дмитренко}

За результатами проведених досліджень в окремих господарствах Полтавського району Полтавської області встановлено, щзо поширення виразкового глоситу серед великої рогатої худоби коливається від 0 до 57,9\% у корів та від 0 до 57,2 \% - телят, щчо вказує на те, щзо корови хворіють частіше за телят. Отримані дані та аналіз літературних джерел свідчать про значне поширення виразкового глоситу $у$ великої рогатої худоби як в Україні, так $і$ за їі межами.

Ключові слова: тварини, велика рогата худоба, корови, телята, виразковий глосит, поширення.

Постановка проблеми. Виразка язика (ulcus linguae) - це порушення цілісності слизової оболонки і прилеглих до неї тканин в результаті їх некрозу з наступним відторгненням, що повільно загоюється внаслідок лізису клітинних елементів та розвитку патологічних грануляцій $[1,2,4-6]$. За даними літературних джерел [9-12] виразковий глосит у великої рогатої худоби є значно поширеним у різних країнах, тому вивчення цієї патології залишається актуальним.

Аналіз останніх досліджень і публікацій, у яких започатковано розв'язання проблеми. У попередніх публікаціях нами було наведено поширення виразкового глоситу у великої рогатої худоби в різних районах Полтавської, Харківської, Сумської областей $[3,7,8]$, за даними м'ясопереробних підприємств. Водночас проаналізовано літературні джерела і встановлено, що дослідження щодо поширення досліджуваної нами патології на теперішній час на території України не проводилися, тому було доцільно вирішити це завдання.

Мета досліджень - вивчення поширення виразкового глоситу язика у великої рогатої худоби в окремих господарствах Полтавської області.

Для іiі досягнення одним із завдань було: проаналізувати результати диспансеризації корів i телят, встановити кількість хворих тварин та частку патології у стаді.

Матеріали і методи досліджень. Вивчення поширення патології проводили, аналізуючи результати диспансеризації тварин в окремих гос- подарствах Полтавського району Полтавської області в період 2009-2010 років.

Роботу проводили на базі чотирьох аграрних господарств різних форм власності Полтавської області: ДП ДГ «Степне» Полтавського інституту свинарства i АПВ НААН; СТОВ СС «Тростянець»; ДП СП «Ювілейне»; ТОВ «Дукла».

Визначали загальну кількість тварин із кожного господарства, хворих на виразковий глосит та їх частку у стаді.

Дослідження виконані відповідно до Закону України «Про захист тварин від жорстокого поводження» (2007), з дотриманням концепції 3R згідно з загальними принципами експериментів на тваринах, які ухвалені на Першому національному конгресі з біоетики (Київ, 2001) та узгоджені з положеннями Свропейської конвенції про захист хребетних тварин, яких використовують для експериментів та інших наукових цілей (Страсбург, 1985). Об'єктом дослідження була велика рогата худоба (корови, телята 4-6- і молодняк 6-9-місячного віку) української чорнорябої породи. Досліджено 1160 корів, з яких 305 (26,3\%) хворі на виразковий глосит, та 567 телят, $з$ яких 79 - хворі (13,9\%).

Результати досліджень наведені в таблиці.

Аналізуючи отримані дані, можна зазначити, що виразковий глосит у великої рогатої худоби в окремих господарствах Полтавського району мав поширення від 0 до 57,9\%.

У агроформуванні ДП ДГ «Степне» серед дослідженого поголів'я ураження язика виявлено не було, що, на нашу думку, пов'язане з повноцінною годівлею та утриманням тварин. Натомість, у СТОВ «Спілка селян “Тростянець”» виразковий глосит реєстрували у 59 корів та 16 телят шестимісячного віку, що становило 25,5 i 26,2 \% відповідно.

Поширеною патологія язика була і в господарстві ДП СП «Ювілейне», де серед 250 корів дійного гурта та 171 молодняка старше шестимісячного віку було виявлено відповідно 33,6 i $27,5 \%$ хворих тварин. 
Поширення виразкового глоситу великої рогатої худоби в господарствах Полтавської області

\begin{tabular}{|c|c|c|c|c|c|c|}
\hline Господарство & 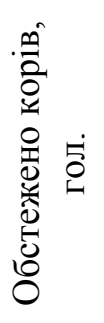 & 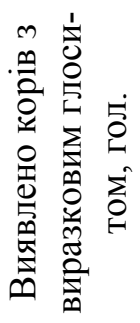 & 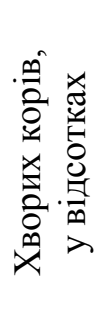 & 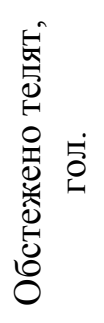 & 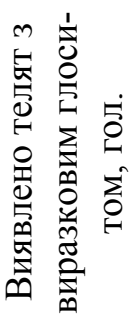 & 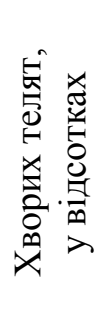 \\
\hline ДП ДГ «Степне» & 400 & - & - & 307 & - & - \\
\hline СТОВ СС «Тростянець» & 231 & 59 & 25,5 & 61 & 16 & 26,2 \\
\hline ДП СП «Ювілейне» & 250 & 84 & 33,6 & 171 & 47 & 27,5 \\
\hline ТОВ «Дукла» & 280 & 162 & 57,9 & 28 & 16 & 57,2 \\
\hline Усього & 1161 & 305 & 26,3 & 567 & 79 & 13,9 \\
\hline
\end{tabular}

У ТОВ «Дукла» клінічно обстежено 280 корів та 28 голів молодняка, серед яких у 162 корів $(57,9 \%)$ та 16 телят (57,2\%) діагностовано виразку язика, що відповідало найбільшому відсотку ураження поголів'я серед господарств, у яких проводились дослідження. Таким чином, результати обстеження свідчать про те, що виразковий глосит реєструється у $0-57,2 \%$ телят та $0-57,9 \%$ корів, у середньому у 13,9 і 26,3\%. Отже, корови хворіють частіше за те-

\section{БІБЛІОГРАФІЯ}

1. Заболевание слизистой оболочки полости рта : учеб. пособ. / [Данилевский Н. Ф., Леонтьев В. К., Несин А. Ф., Рахний Ж. И.]. - М. : ОАО «Стоматология», 2001. $-272 \mathrm{c.}$

2. Заболевание слизистой оболочки полости рта и губ : [под ред. проф. Е. В. Боровского, проф. А. Л. Машкиллейсона]. - М. : Медицина, 1984. $-400 \mathrm{c}$.

3. Канівець Н. С. Поширення виразки язика у великої рогатої худоби у господарствах центрального регіону України / Н. С. Канівець // Вісник ПДАА. - Полтава : РВВ ПДАА. - 2014. - №4. C. $123-125$.

4. Платонов E. E. Заболевания языка и их терапия / Е. Е. Платонов. - М., 1937. - 83 с.

5. Рабинович И. М. Заболевания слизистой оболочки полости рта / И. М. Рабинович, Г.В. Банченко // Стоматология для всех. - М., 1998. - №3 (4). - C. 16-19.

6. Спеціальна ветеринарна хірургія : підруч. / [Панько I. С., Власенко В. М., Гамота А. А. та ін.] ; за ред. І. С. Панька. - Біла Церква : Білоцерків. держ. аграр. ун-т, 2003. - С. 39-40.

7. Ульянко Н. С. Поширення виразкової хвороби язика великої рогатої худоби у віковому лят. Можливо, така тенденція пов'язана з порушенням умов годівлі та утримання тварин. Це, безперечно, спонукає нас до пошуку чинників, які сприяють проявам цієї патології.

Висновок. За результатами проведених досліджень в окремих господарствах Полтавського району Полтавської області встановлено, що поширення виразкового глоситу серед корів коливається від 0 до $57,9 \%$ у корів, та від 0 до $57,2 \%$ - у телят.

аспекті в господарствах Полтавського району Полтавської області / Н. С. Ульянко // Підсумки наук.-дослід. роботи технологічних ф-тів за 2009 рік : наук.-практ. конф. проф.-виклад. складу ; мат. конф. - Полтава, 2010. - С. 99-100.

8. Ульянко Н. С. До питання патогенезу виразкової хвороби язика у великої рогатої худоби / Н. С. Ульянко // Вісник ПДАА. - Полтава : РВВ ПДАА. - 2010. - №2. - С. 195-196.

9. Enzootic ulcer in the back of the tongue in cattle after ingestion of hay containing flower clusters of yellow bristle-grass / [Fava E., Rossi F., Speranzini G. et.al.] // Dtsch. Tierarztl. Wochenschr. 2000. - №107 (9). - P. 351-354.

10. Gill D. R. Tongue Lesions: incidence and effects on performance of feedlot cattle / D. R. Gill, R. G. Panciera, R. A. Smith // Animal Science Research Report. - 1996. - P. 207-210.

11. Isolation of viral agents fromcattle with chronic ulcerative glossitis / [Flammini C. F., Cavirani S., Allergi G., Zanichelli L.] // Atti Soc. Ital. Buiatria. - 1985. - №17. - P. 597-607.

12. Jones T. S. Veterinary patology / T. S. Jones, R. D. Hunt, N. W. King. - [6-th, end.]. - Pennsylvania : William and Wilkins, 1997. - P. 1043-1046. 